Christos C. Zouboulis · John J. Voorhees

Constantin E. Orfanos - Amir Tavakkol

\title{
Topical all-trans retinoic acid (RA) induces an early, coordinated increase in RA-inducible skin-specific gene/psoriasin and cellular RA-binding protein II mRNA levels which precedes skin erythema
}

Received: 5 February 1996

\begin{abstract}
Separation of specific and nonspecific "irritant" effects of topical all-trans retinoic acid (RA) is a key to understanding the mechanism of retinoid action in skin. Cellular RA-binding protein (CRABP) II has been found to be a marker of RA activity in human skin. We have also previously identified a skin-specific gene (RIS-1/psoriasin) which is rapidly induced in human skin treated with RA. Here we compared the kinetics and time-course of RIS-1 and CRABP II gene activation by RA, sodium lauryl sulfate (SLS), a classical irritant, and their vehicle (VH), using a quantitative reverse transcription polymerase chain reaction. RIS-1 and CRABP II were both expressed at very low levels in untreated normal human skin, and in RA-treated skin the kinetics and time course of RIS-1 and CRABP II mRNA induction were similar. Relative to VH-treated skin, RA induced RIS-1 mRNA levels within $6 \mathrm{~h}$, which further increased to 6.4-fold by $24 \mathrm{~h}(n=4)$. Similarly, CRABP II mRNA levels increased from 2.6 -fold at $6 \mathrm{~h}$ to 7.8 fold after $24 \mathrm{~h}$. At $48 \mathrm{~h}$ the relative mRNA levels for both genes decreased towards the steady-state levels. Relative to SLS-treated skin, RIS-1 mRNA increased by 3.2-fold after $6 \mathrm{~h}$ and by 5.1 -fold after $12 \mathrm{~h}(n=3)$. Also, a 2.6-fold higher CRABP II mRNA observed after $6 \mathrm{~h}$ increased to 6-fold after $12 \mathrm{~h}$. After 24 and $48 \mathrm{~h}$ RA treatment the relative mRNA levels for both genes
\end{abstract}

C. C. Zouboulis $(凹) \cdot$ C. E. Orfanos

Department of Dermatology,

University Medical Center Benjamin Franklin,

The Free University of Berlin, Hindenburgdamm 30,

D-12200 Berlin, Germany

Tel. 49-30-84452769; Fax 49-30-84454262

e-mail: zoubbere@fub46.zedat.fu-berlin.de

J. J. Voorhees

Department of Dermatology,

University of Michigan Medical Center,

1910 A. Alfred Taubman Health Care Center,

Ann Arbor, MI 48109-0314, USA

A. Tavakkol

Colgate-Palmolive Company, Skin Clinical Investigations Group, 909 River Road, Piscataway, NJ 08855-1343, USA decreased towards the steady-state levels. RA-induced skin erythema was not obvious until 24 to $48 \mathrm{~h}$. We conclude, therefore, that induction of RIS-1 and CRABP II mRNA levels by topical RA in human skin are early, coordinated molecular events which precede the clinical cutaneous erythematous response to RA.

Key words Retinoic acid · Human skin · RIS-1/ psoriasin gene · CRABP II gene - Quantitative RT-PCR

\section{Introduction}

Although topical all-trans retinoic acid (RA) produces characteristic epidermal changes and induces dermal repair in photoaged skin $[10,13,21,25]$, it is uncertain whether these effects are retinoid-specific. To address this question the effects of sodium lauryl sulfate (SLS), a local irritant, and RA on human skin have been previously compared. While local erythema, histologic changes, and increases in epidermal transglutaminase and involucrin have been found to be indistinguishable for RA and SLS [8, 10, 12], RA specifically induces cellular RA-binding protein (CRABP) II [7] and RA-4 hydroxylase [5].

On the other hand, it is also still uncertain whether RAinduced clinical efficacy and irritation are two separate or associated phenomena. The presumption of separate events is supported by similar effects of $0.1 \%$ and $0.025 \%$ RA on clinical and histologic changes in facial photodamage and by dissociated irritant activity: $0.1 \%$ RA induces significantly greater irritation than $0.025 \%$ RA [14]. In contrast, experiments using the rhino mouse utriculi reduction and rabbit irritation models have shown that efficacy and irritation are associated RA effects mediated by the RA receptor (RAR)- $\gamma$ [4]. Significant work on the two families of retinoid receptors, namely the RARs and the retinoid $\mathrm{X}$ receptors, as well as on the CRABPs I and II has provided some explanations for the overall mechanism of action of retinoids [1, 6, 9, 11]. Moreover, first evidence has been provided that the so-called retinoid effects in skin are mediated by these same molecules $[4,16]$. 
As a first step towards the identification of genes that are the target of RA action in skin, we previously utilized the differential hybridization screening of a cDNA library constructed from RA-treated human skin. An RA-inducible skin-specific gene (RIS-1) was isolated whose expression is restricted to skin and appears to encode a protein highly homologous to psoriasin [30]. Psoriasin was shown to be induced in psoriatic epidermis [24], certain other inflammatory diseases [27], and in keratinocytes after RA treatment in vitro [18]. Interestingly, CRABP II, which has been suggested to be a marker of RA activity in human skin [7], is also induced in psoriatic skin $[6,31]$. In addition, RA-induced skin inflammation in the CRABPs knockout mouse model has been recently shown to be dependent on CRABPs [16].

Using a sensitive quantitative reverse transcription polymerase chain reaction (RT-PCR) technique we detected a coordinated upregulation of RIS-1/psoriasin and CRABP II by RA. We also found that RIS-1/psoriasin and CRABP II responses to topical RA treatment are early molecular events which precede RA-induced skin erythema.

\section{Materials and methods}

\section{Bioassay and RNA extraction}

Seven normal volunteers were included in the study after giving written consent in a protocol approved by the University of Michigan Medical Center Institutional Review Board. They were treated with $0.1 \%$ RA cream (Retin A, Ortho Pharmaceuticals, Raritan, N.J.), its vehicle (VH) cream or 2\% SLS (DuPont, Wilmington, Del.) in VH cream applied to adjacent areas of buttock skin $\left(150 \mathrm{mg}\right.$ per $\left.9 \mathrm{~cm}^{2}\right)$ under occlusion with plastic wrap [12]. After 6 to $48 \mathrm{~h}$, the occlussive patch was removed and the degree of erythema present at each test site scored according to a ten-point scale where $0=$ none, $1-3=$ mild, $4-6=$ moderate, and $7-10=$ severe. Untreated skin served as an additional control. Keratome biopsies were obtained under local anaesthesia with $1 \%$ lidocaine, immediately frozen in liquid nitrogen and stored at $-70^{\circ} \mathrm{C}$ until use.

Total RNA was isolated by the guanidinium isothiocyanate-cesium chloride procedure and stored at $-70^{\circ} \mathrm{C}$ until use. RNA concentrations were determined by absorbance at $260 \mathrm{~nm}$.

\section{RT-PCR}

All RT stock solutions were prepared in advance and stored at $-70^{\circ} \mathrm{C}$ until use [3]. A stock solution of random hexamers $(2.5$ $\mu M)$ in diethylpyrocarbonate-treated double-distilled water was mixed with a stock solution of RNasin (30 U; Promega, Madison, Wis.), dATP, dCTP, dGTP, and dTTP (500 $\mu M$ each; PerkinElmer Cetus, Norwalk, Ct.), and MMLV reverse transcriptase (200 U; Gibco-BRL, Gaithersburg, Md.), in a buffer of Tris-HCl (50 $\mathrm{m} M, \mathrm{pH} 8.3), \mathrm{KCl}(75 \mathrm{~m} M), \mathrm{MgCl}_{2}(3 \mathrm{~m} M)$, and dithiothreitol (10 $\mathrm{m} M$ ). RNA was finally added and the RT was carried out in a total volume of $30 \mu \mathrm{l}$ at $37^{\circ} \mathrm{C}$ for $1 \mathrm{~h}$ and $75^{\circ} \mathrm{C}$ for $10 \mathrm{~min}$. In every case samples containing no RNA (negative control) or no reverse transcriptase were included to exclude contamination of the reagents with PCR products and amplification from contaminating DNA, respectively. Additionally, all primers used were exon-specific to avoid amplification of genomic fragments, as previously described [28]. The resulting cDNA was stored at $-70^{\circ} \mathrm{C}$.
For cDNA or DNA amplification by PCR a stock solution of oligonucleotide primers (500 ng each) in double-distilled water was mixed with a stock solution of dATP, dCTP, dGTP and dTTP (200 $\mu M$ each; Perkin-Elmer Cetus), and recombinant Taq DNA polymerase (5 U; Gibco-BRL) in a buffer of Tris- $\mathrm{HCl}(10 \mathrm{mM}, \mathrm{pH}$ $8.3), \mathrm{KCl}(50 \mathrm{~m} M)$, and $\mathrm{MgCl}_{2}(1.5 \mathrm{~m} M)$. cDNA (1 $\mu 1 \mathrm{RT}$ product) or plasmid DNA was finally added and the PCR was performed in a total volume of $50 \mu \mathrm{l}$. The reaction was initiated at $94^{\circ} \mathrm{C}$ for 2 min, each cycle of amplification consisted of $1 \mathrm{~min}$ denaturation at $92^{\circ} \mathrm{C}$, followed by $1 \mathrm{~min} 30 \mathrm{~s}$ annealing at $55^{\circ} \mathrm{C}$, and $1 \mathrm{~min} 30 \mathrm{~s}$ extension at $72^{\circ} \mathrm{C}$. The final product was extended for $10 \mathrm{~min}$. In every case the RT controls and a PCR negative control (without DNA) were included.

\section{Northern and DNA blot analyses}

Total RNA $(30 \mu \mathrm{g})$ was size-fractionated by electrophoresis in $1 \%$ formaldehyde-agarose gels containing $0.2 \mu \mathrm{g} / \mathrm{ml}$ ethidium bromide and transferred to nylon membranes (Zeta-Probe, BioRad, Richmond, Calif.). The PCR products were subjected to electrophoresis through $1.8 \%$ agarose gels containing $0.5 \mu \mathrm{g} / \mathrm{ml}$ ethidium bromide and transferred to nylon membranes (Zeta-Probe). Complete transfer of RNA or DNA was confirmed by examining the gels under UV light.

The blots were sequentially hybridized against ${ }^{32} \mathrm{P}-\mathrm{dCTP}$ cDNA probes (specific activity $1.5 \times 10^{8} \mathrm{cpm} / \mu \mathrm{g}$ DNA) labeled by the random priming technique at concentrations of $1.5 \times 10^{6}$ $\mathrm{cpm} / \mathrm{ml}$ hybridization buffer for Northern blots and $0.5 \times 10^{6}$ $\mathrm{cpm} / \mathrm{ml}$ for DNA blots. The prehybridization and hybridization procedures of the Northern blots have been described elsewhere [2]. Prehybridization and hybridization of DNA blots were performed at $63^{\circ} \mathrm{C}$ in a buffer containing sodium dodecyl sulfate (7\% w/v, $\mathrm{pH} 7.0)$, EDTA (1.25 $\mathrm{m} M, \mathrm{pH} 8.0)$, and sodium phosphate (0.5 M, pH 7.0).

Northern and DNA blots were quantitated by the storage phosphor imaging technique, as previously described [32]. The blots were exposed to imaging screens (Molecular Dynamics, Sunnyvale, Calif.) for $3 \mathrm{~h}$ at room temperature. The screens were then scanned using a Molecular Dynamics PhosphorImager $400 \mathrm{E}$ at a scanning speed of $50 \mu$ s per $88 \mu \mathrm{m}$ pixel and the signal areas were viewed on a video monitor and quantitated using image analysis software (ImageQuant Version 3.22, Molecular Dynamics). When appropriate, the intensities of integrated signals were normalized to control genes by dividing the intensity obtained for the test gene by that of the control gene. Background signal was automatically subtracted.

\section{Oligonucleotide primers and DNA probes}

Transcripts of RIS-1, CRABP II, and RAR $\gamma_{1}$ were studied by amplification of cDNA derived from transcribed RNA using specific primer pairs of 19-22 nucleotides in length with 42-68\% GC composition, as follows: Common RIS-1/psoriasin primer 1 (5'-TTACCTCGCCGACGTCTTTG-3'), primer 2 (5'-TCACTGGCTGCCCCCGGAA-3'), CRABP II primer 1 (5'-CAACTGGAAAATCATCCGA-3'), primer 2 (5'-CAACGTCATCCGC[C/T]GTCAT-3'), RAR $\gamma_{1}$ primer 1 (5'-GCCACCAATAAGGAGCGACTCT-3'), primer 2 (5'-TCAGGGTTCTCCAGCATCTCTC-3') [22]. All primers were synthesized by the University of Michigan DNA core facility. The cDNA amplification products, spanning 50 $90 \%$ of the known coding sequence, were predicted to be $148 \mathrm{bp}$ (RIS-1/psoriasin), $371 \mathrm{bp}$ (CRABP II), and $1256 \mathrm{bp}\left(\mathrm{RAR} \gamma_{1}\right)$ in length (the distance between primers plus primer lengths). The identity of the PCR products was confirmed by enzyme restriction mapping.

The RIS-1 and CRABP II probes were purified fragments from human RIS-1 cDNA [30] and human CRABP II cDNA [2]. The isoform-specific RAR- $\gamma_{1}$ probe was a gift from Prof. P. Chambon, Strasbourg, France [20]. The 36B4 probe was kindly provided by Dr. J.T. Elder, University of Michigan, Ann Arbor, Mich. [23]. 
15 cycles $\quad$ Dg DNA 17 cycles

10
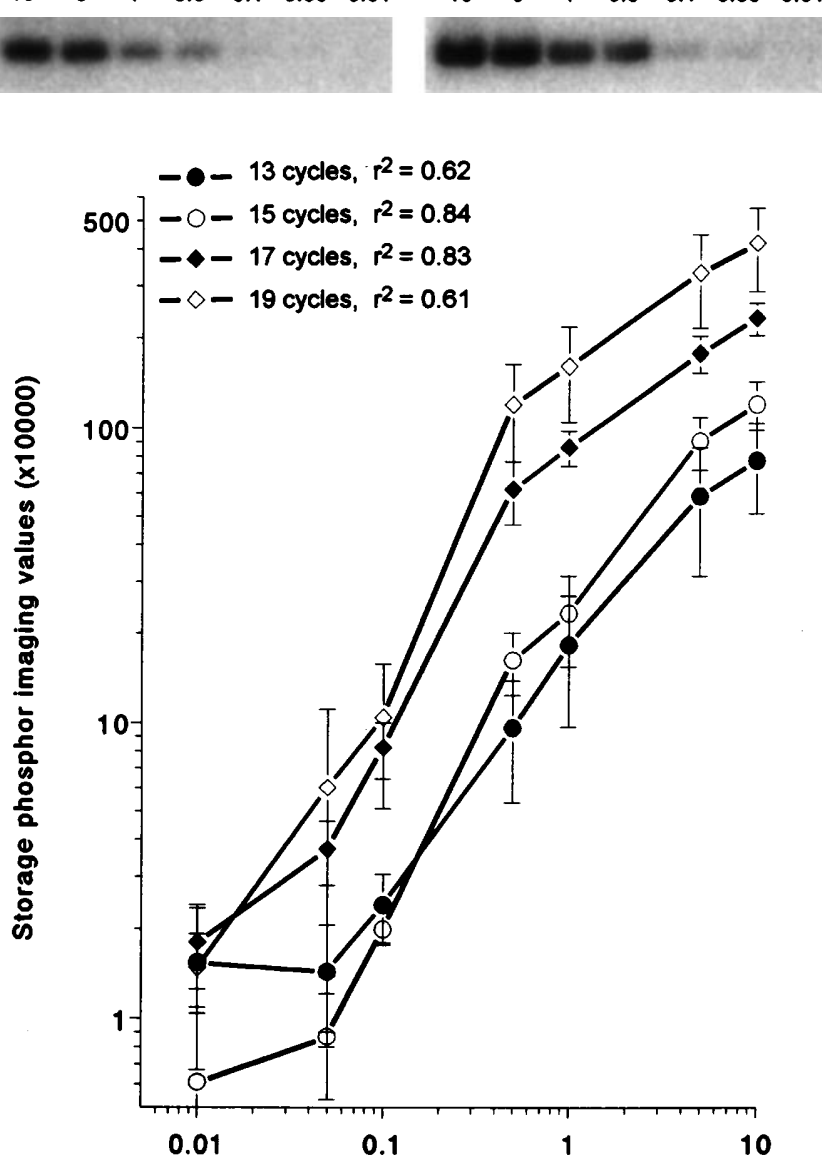

a

RIS-1 DNA concentration in $\mathbf{n g} / \mathbf{m l}$

Fig. 1a, b Determination of optimum number of PCR cycles for linear correlations between amounts of DNA template and PCR products. After RT-PCR, DNA amplicons were run on gels, transferred to nitrocellulose membranes and hybridized to ${ }^{32} \mathrm{P}$-labeled RIS-1 (a) and CRABP II (b) cDNA probes. DNA concentrations were plotted against the pixel values obtained by storage phosphor imaging analysis known to correlate with signal intensity [32]. The coefficient of correlation $\left(r^{2}\right)$ calculated by linear regression was optimal at 15 to 17 PCR cycles for RIS- 1 and 19 to 21 PCR cycles for CRABP II. Increasing or reducing the number of cycles significantly diminished $r^{2}$ values. Independent experiments were performed in triplicate. Error bars mean \pm SEM

\section{Results}

\section{Quantitative RT-PCR}

We first determined the optimum number of PCR cycles for producing the best linear correlation between the amounts of DNA template and the PCR products. Varying amounts of DNA template for RIS-1, CRABP II and $\operatorname{RAR} \gamma_{1}(0.001-10 \mathrm{ng} / \mathrm{ml}$ in increments of tenfold) were amplified for 10 to 35 cycles (in steps of 5 cycles). Subsequently, a narrowed area of DNA concentrations (0.01-10 ng/ml) and PCR cycles (11-25) were selected and the experiments were repeated using DNA concentra-

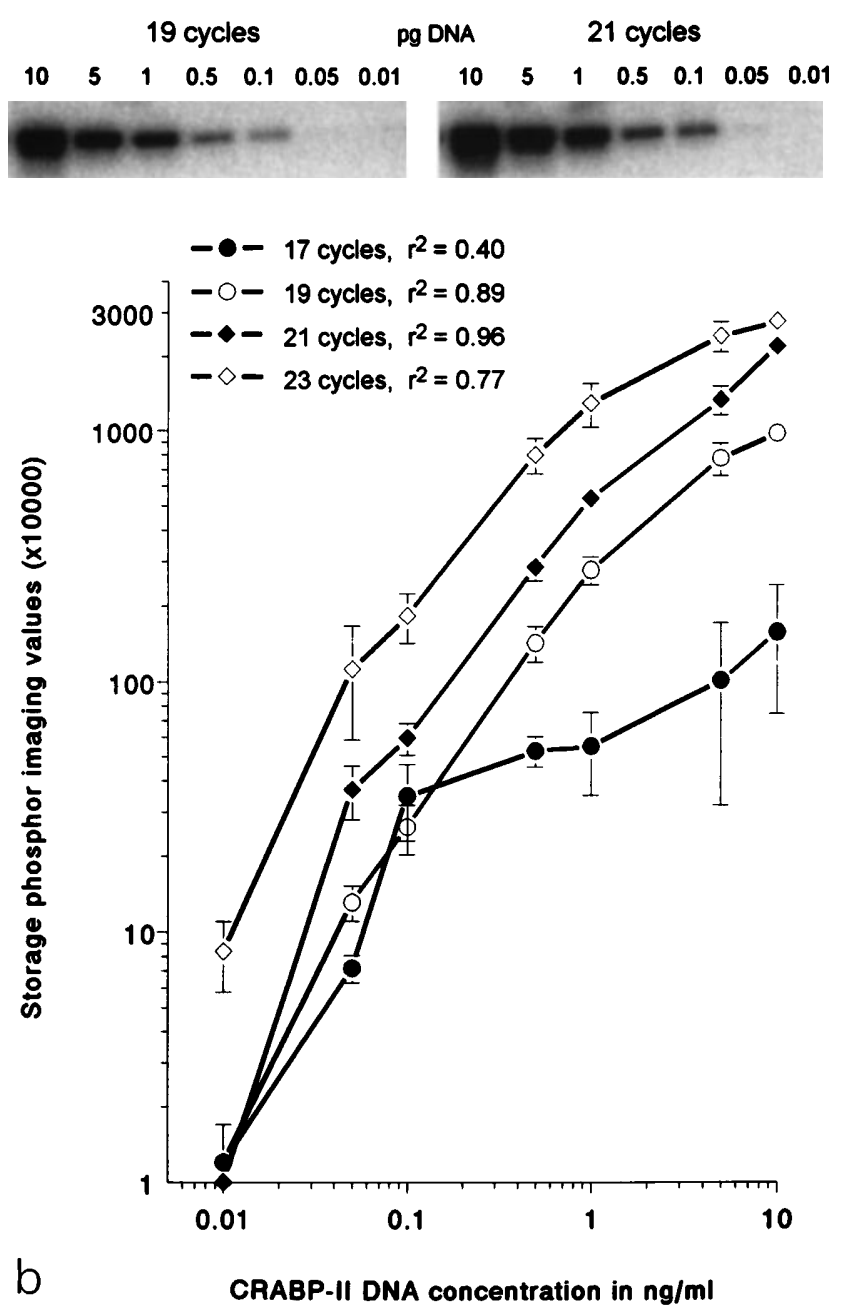

tions in increments of five- to twofold and PCR cycles in steps of 2. Triplicate independent experiments were performed to verify the reproducibility of the method.

A linear correlation between the increase in the intensity of radioactive signals with that of DNA amount was found at DNA concentrations ranging from 0.01 to 5 $\mathrm{ng} / \mathrm{ml}$ for all three genes. The PCR cycles needed to obtain a linear correlation varied, however, from 15-17 cycles for RIS-1 to 19-21 cycles for CRABP II and RAR $\gamma_{1}$ (Fig. 1). Fewer or more cycles significantly decreased the coefficient of correlation $\left(r^{2}\right)$ between the two parameters.

Subsequently, RT of different RNA amounts (0.125-2 $\mu \mathrm{g})$ from RA- and SLS-treated skin and PCR amplification of $1 \mu \mathrm{l}$ of the RT products were performed using 16 PCR cycles for RIS- 1 and 20 cycles for CRABP II and $\operatorname{RAR} \gamma_{1}$. The results of the assessment of the quantitated hybridization signals obtained by RT-PCR of $0.5-1 \mu \mathrm{g}$ RNA were similar to those found by Northern blotting.

Modulation of RIS-1 and CRABP II gene expression in RA-treated skin

RNA $(1 \mu \mathrm{g})$ from skin treated with RA and VH for $6-48 \mathrm{~h}$ $(n=4)$, or with RA and SLS for 6-48 h $(n=3)$, and from 

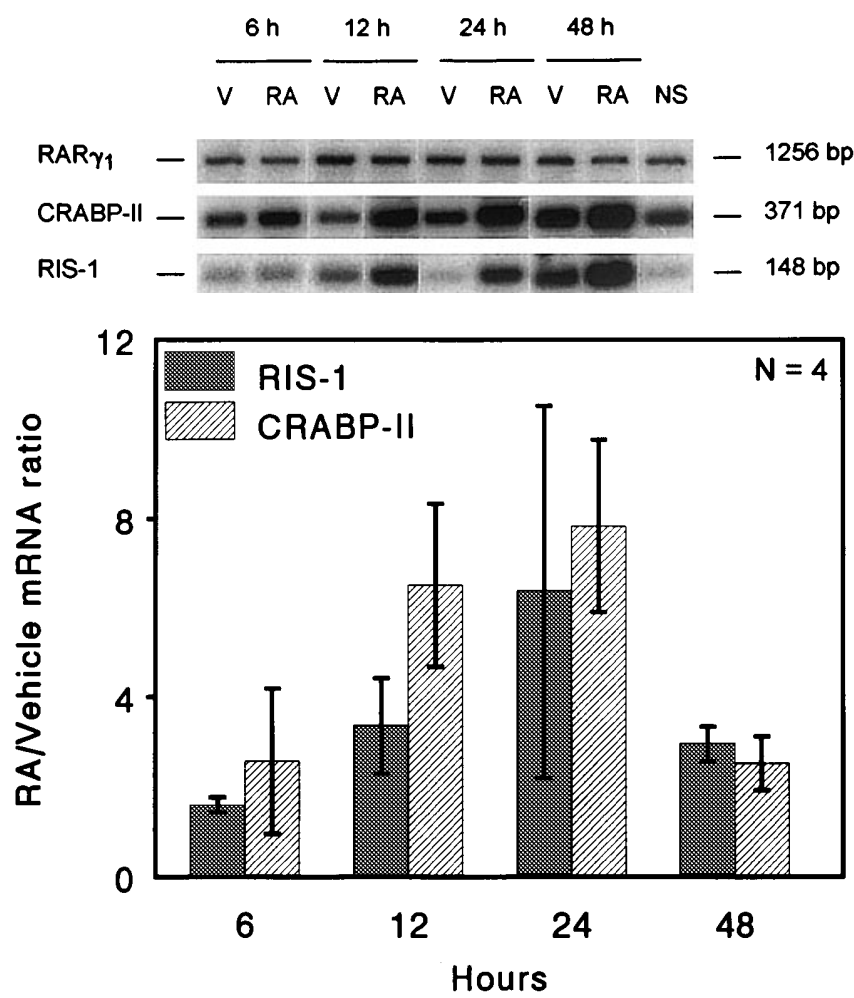

Fig. 2 Time course of RIS-1 and CRABP II mRNA response to RA $0.1 \%$ relative to vehicle $(V)$ treatment evaluated by quantitative RT-PCR $(n=4)$ ( $N S$ normal untreated skin). RAR $\gamma_{1}$ was used as a control gene not regulated by RA or vehicle. Error bars median \pm SEM
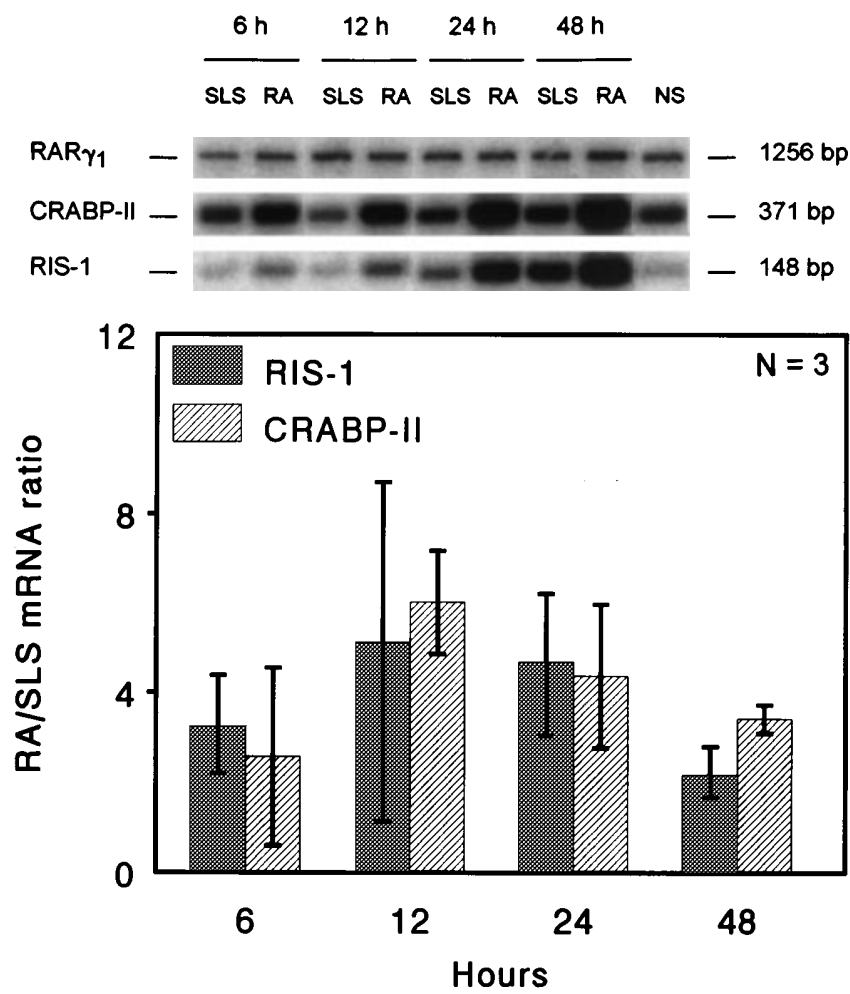

Fig. 3 Time course of RIS-1 and CRABP II mRNA response to RA $0.1 \%$ relative to SLS $2 \%$ treatment evaluated by quantitative RTPCR $(n=3)$ ( NS normal untreated skin). RAR $\gamma_{1}$ was used as a control gene not regulated by RA or SLS. Error bars median \pm SEM untreated skin ( $n=4)$ was used to quantify RIS-1 and CRABP II mRNA levels by quantitative RT-PCR. RAR $\gamma_{1}$ mRNA, whose levels have been shown not to be influenced by RA in the skin [6, 29], was used as an internal control.

RIS-1 and CRABP II transcripts were detected in untreated human skin by RT-PCR but not by Northern analysis. The kinetics and time-course of RIS-1 and CRABP II mRNA induction by RA were similar. Compared to VHtreated skin, we found a 1.6-fold higher RIS-1 mRNA level and a 2.6-fold higher CRABP II mRNA level in RAtreated skin after $6 \mathrm{~h}$. These further increased by 3.4-fold (RIS-1) and 6.5-fold (CRABP II) after $12 \mathrm{~h}$, and 6.4-fold (RIS-1) and 7.8-fold (CRABP II) after $24 \mathrm{~h}$ (Fig. 2). In contrast, only a 3-fold higher RIS-1 mRNA level and a 2.5-fold higher CRABP II mRNA level were observed after $48 \mathrm{~h}$. Compared to SLS-treated skin, there was a 3.2-fold relative increase in RIS-1 mRNA level and a 2.6fold increase in CRABP II mRNA level in RA-treated skin after $6 \mathrm{~h}$. RA induced RIS-1 by 5.1-fold and CRABP II by 6 -fold after $12 \mathrm{~h}$, but only by 4.7 -fold and 4.4 -fold after $24 \mathrm{~h}$, and 2.2-fold and 3.4-fold after $48 \mathrm{~h}$, respectively (Fig. 3). The magnitude of increase in RIS-1 and CRABP II mRNA levels following RA treatment varied considerably between individuals. However, there was an almost uniform marked increase in RIS-1 and CRABP II mRNA levels at $48 \mathrm{~h}$ compared to earlier time-points or to untreated skin.

Northern analysis of the same RNA specimens confirmed the results obtained by quantitative RT-PCR (Fig. 4). Because of the low levels of RAR $\gamma_{1}$ mRNA, 36B4 transcript levels, which have also been shown to be unaffected by RA treatment in the skin [17, 23], were used as an internal control.

\section{Clinical results}

There were no significant differences in erythema induced at the test sites by RA, SLS or VH. However, more patients developed erythema following RA treatment $(n=3)$ than following SLS $(n=1)$ or VH treatment $(n=1)$ at $48 \mathrm{~h}$ (Table 1). RA did not induce erythema until $24 \mathrm{~h}$, and SLS and VH until $48 \mathrm{~h}$.

\section{Discussion}

RIS-1/psoriasin and CRABP II mRNAs are expressed either at low levels or are not detectable in adult human skin (this study; [2, 6, 7, 17, 29-31]). Consistent with previous reports [7, 30], relative RIS-1/psoriasin and CRABP II mRNA levels rapidly increased following RA treatment (within $6 \mathrm{~h}$ ) in comparison to the effects of VH and SLS in the present work. It appears, therefore, that RIS-1/psoriasin and CRABP II responses to RA are time-dependent effects which occur very early under topical RA treatment. At $24-48 \mathrm{~h}$, relative mRNA levels decreased towards the steady-state levels. This was due to a net induc- 
Fig. 4 Time course of RIS-1 and CRABP II mRNA response to RA $0.1 \%$ relative to vehicle $(V)$ treatment evaluated by Northern analysis $(n=4)$ (NS normal untreated skin). Representative results of two individuals at every time-point are presented. 36B4 was used as a control gene not regulated by RA or vehicle. Error bars median \pm SEM
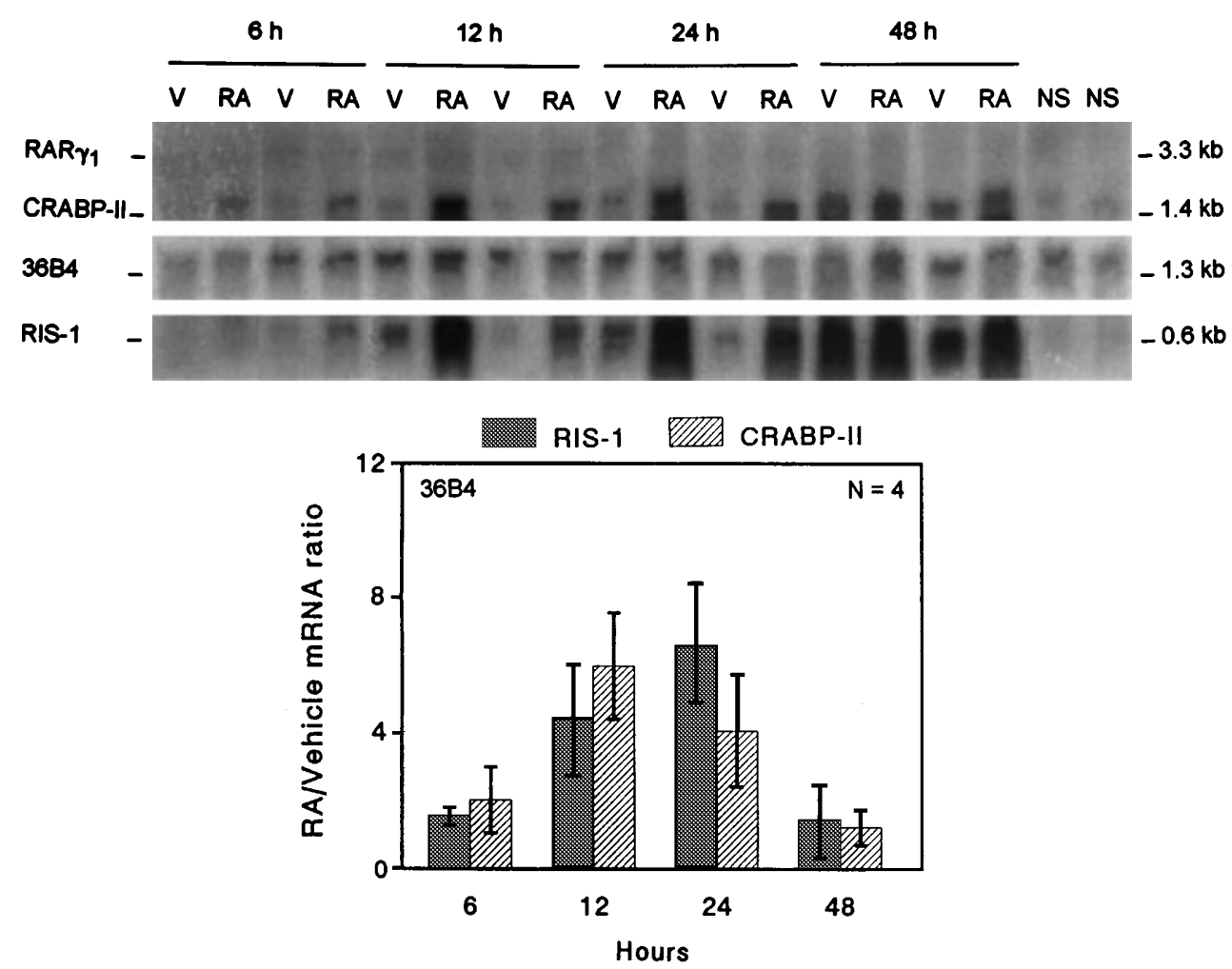

Table 1 Time course of erythema induced in test sites by retinoic acid, sodium lauryl sulfate and their vehicle (degree of erythema: $0=$ none, $1-3=$ mild, $4-6=$ moderate $7-10=$ severe)

\begin{tabular}{|c|c|c|c|c|c|c|}
\hline \multirow{2}{*}{$\begin{array}{l}\text { Time } \\
\text { (h) }\end{array}$} & \multicolumn{2}{|c|}{ Retinoic acid } & \multicolumn{2}{|c|}{ Sodium lauryl sulfate } & \multicolumn{2}{|l|}{ Vehicle } \\
\hline & Patients & Erythema score & Patients & Erythema score & Patients & Erythema score \\
\hline 6 & $0 / 7$ & 0 & $0 / 7$ & 0 & $0 / 7$ & 0 \\
\hline 12 & $0 / 7$ & 0 & $0 / 7$ & 0 & $0 / 7$ & 0 \\
\hline 24 & $1 / 7$ & $0.1 \pm 0.4$ & $0 / 7$ & 0 & $0 / 7$ & 0 \\
\hline 48 & $3 / 6$ & $1.2 \pm 1.6$ & $1 / 6$ & $0.5 \pm 1.2$ & $1 / 6$ & $0.2 \pm 0.4$ \\
\hline
\end{tabular}

tion of RIS-1/psoriasin and CRABP II mRNA levels by VH (at $48 \mathrm{~h}$ ) and SLS (at 24-48 h) in occluded skin. A simultaneous net decrease in skin response to RA treatment has been previously excluded [30]. A similar decrease after an initial increase of Egr-1 expression has been reported [15], which can be induced by topical RA in vivo using the same experimental procedure [12].

A discrepancy exists concerning the association of CRABP II mRNA induction by RA and cutaneous RA irritant effects. CRABP II expression was found to increase with epidermal stratification induced by RA [6, 29]. RA-upregulated CRABP II mRNA and protein levels in human skin are downregulated by topical glucocorticoids [26]. Interestingly, topical glucocorticoids clinically diminish the irritation produced by RA [21]. Recently, there have been further contradictory findings. Dissociation of epidermal changes as well as erythema and CRABP II mRNA expression induced by RA in human skin have been shown [1, 11], and modulation of RA-induced skin inflammation by CRABPs in CRABPs knockout mice has been detected [16]. On the other hand, RIS-1/psoriasin expression, which is also induced by topical RA in human skin (this study; [30]) and in cultured keratino- cytes [18], has been shown to be upregulated in several inflammatory skin diseases [27] and its protein has been found to be a selective chemokine for $\mathrm{CD}^{+} \mathrm{T}$ lymphocytes and neutrophils [19].

The present study showed that increasing CRABP II and RIS-1/psoriasin mRNA levels were not concurrent with RA-induced skin erythema, but the early, coordinated induction of both genes preceded the clinical response to RA. Theoretically, it is possible that RA-induced inflammation partly utilizes RIS-1/psoriasin as a chemoattractant agent for recruiting inflammatory cells [19] and CRABP II as a modulator of RA activity [16]. Although a delayed induction of CRABP II and RIS1/psoriasin mRNA levels was also detected by SLS and later by $\mathrm{VH}$ under skin occlusion, an early induction of expression of these two genes seems to represent a retinoid-specific event.

Acknowledgements We thank Prof. Christopher E.M. Griffiths and Robin Gardner for procurement of human skin biopsies and for providing the clinical data. This work was supported in part by the R.W. Johnson Pharmaceutical Research Institute, the Babcock Research Endowment, USA, and The Free University of Berlin, Germany. 


\section{References}

1. Asselineau D, Cavey M-T, Shroot B, Darmon M (1992) Control of epidermal differentiation by a retinoid analogue unable to bind to cytosolic retinoic acid-binding proteins (CRABP). J Invest Dermatol 98:128-134

2. Åström A, Tavakkol A, Pettersson U, Cromie M, Elder JT, Voorhees JJ (1991) Molecular cloning of two human cellular retinoic acid-binding proteins (CRABP). Retinoic acid-induced expression of CRABP II but not CRABP-I in adult human skin in vivo and in skin fibroblasts in vitro. J Biol Chem 266 17662-17666

3. Chen D, Magnuson VL, Steffensen B, Klebe RJ (1993) Use of stock solutions to simplify mRNA quantitation by reverse transcription-PCR assays. PCR Methods Applic 2:351-353

4. Chen S, Ostrowski J, Whiting G, Roalsvig T, Hammer L, Currier SJ, Honeyman J, Kwasniewski B, Yu K-L, Sterzycki R, Kim CU, Starrett J, Mansuri M, Reczek PR (1995) Retinoic acid receptor gamma mediates topical retinoid efficacy and irritation in animal models. J Invest Dermatol 104:779-783

5. Duell EA, Fishman A, Åström A, Griffiths CEM, Voorhees JJ (1993) In human epidermis all trans retinoic acid is metabolized to the less active 4-hydroxyretinoic acid by a unique cytochrome $\mathrm{P} 450$ that does not metabolize 9-cis or 13-cis retinoic acid. J Invest Dermatol 100:578

6. Elder JT, Åström A, Petterson U, Tavakkol A, Griffiths CEM, Krust A, Kastner P, Chambon P, Voorhees JJ (1992) Differential regulation of retinoic acid receptors and binding proteins in human skin. J Invest Dermatol 98:673-679

7.Elder JT, Cromie MA, Griffiths CEM, Chambon P, Voorhees JJ (1993) Stimulus-selective induction of CRABP II mRNA: a marker for retinoic acid action in human skin. J Invest Dermatol 100:356-359

8. Fischer GJ, Esmann J, Griffiths CEM, Talwar HS, Duell EA, Hammerberg C, Elder JT, Finkel LJ, Karabin GD, Nickoloff BJ, Cooper KD, Voorhees JJ (1991) Cellular, immunologic and biochemical characterization of topical retinoic acid-treated human skin. J Invest Dermatol 96:699-707

9. Gendimenico GJ, Stim TB, Corbo M, Janssen B, Mezick JA (1994) A pleiotropic response is induced in F9 embryonal carcinoma cells and rhino mouse skin by all-trans-retinoic acid, a RAR agonist but not by SR11237, a RXR-selective agonist. J Invest Dermatol 102:676-680

10. Griffiths CEM, Voorhees JJ (1994) Human in vivo pharmacology of topical retinoids. Arch Dermatol Res 287:53-60

11. Griffiths CEM, Elder JT, Bernard BA, Rossio P, Cromie MA, Finkel LJ, Shroot B, Voorhees JJ (1993) Comparison of CD271 (adapalene) and all-trans-retinoic acid in human skin: dissociation of epidermal effects and CRABP II mRNA expression. J Invest Dermatol 101:325-328

12. Griffiths CEM, Finkel LJ, Tranfaglia MG, Hamilton TA, Voorhees JJ (1993) An in vivo experimental model for effects of topical retinoic acid in human skin. Br J Dermatol 129: 389-394

13. Griffiths CEM, Russman AN, Majmudar G, Singer RS, Hamilton TA, Voorhees JJ (1993) Restoration of collagen formation in photodamaged human skin by tretinoin (retinoic acid). N Engl J Med 329:530-535

14. Griffiths CEM, Kang S, Ellis CN, Kim KJ, Finkel LJ, OrtizFerrer LC, White GM, Hamilton TA, Voorhees JJ (1995) Two concentrations of topical tretinoin (retinoic acid) cause similar improvement of photoaging but different degrees of irritation. A double-blind, vehicle-controlled comparison of $0.1 \%$ and $0.025 \%$ tretinoin creams. Arch Dermatol 131:1037-1044

15. Grønhøj Larsen F, Voorhees JJ, Åström A (1994) Retinoic acid induces expression of early growth response gene-1 (Egr-1) in human skin in vivo and in cultured fibroblasts. J Invest Dermatol $102 \cdot 730-733$
16. Heidecker L, Didierjean L, Carraux P, Grand D, Hauser C, Saurat J-H (1995) Topical retinoic acid skin-induced inflammation is CRABP dependent. A study in CRABPs-KO mice. J Invest Dermatol 105:472

17. Hirschel-Scholz S, Siegenthaler G, Saurat J-H (1989) Ligandspecific and non-specific in vivo modulation of human epidermal cellular retinoic acid binding protein (CRABP). Eur J Clin Invest 19:220-227

18. Hoffmann HJ, Olsen E, Etzerodt M, Madsen P, Thøgersen HC, Kruse T, Celis JE (1994) Psoriasin binds calcium and is upregulated by calcium to levels that resemble those observed in normal skin. J Invest Dermatol 103:370-375

19. Jinquan T, Vorum H, Deleuran B, Madsen P, Grønhøj Larsen C, Gesser B, Nielsen V, Celis JE, Thestrup-Pedersen K (1994) Psoriasin is a selective chemokine for CD4+ T lymphocytes and neutrophils. J Invest Dermatol 103:412

20. Kastner P, Krust A, Mendelsohn C, Garnier JM, Zelent A, Leroy P, Staub A, Chambon P (1990) Murine isoforms of retinoic acid receptor $\gamma$ with specific patterns of expression. Proc Natl Acad Sci USA 87:2700-2704

21. Kligman AM, Grove GL, Hirose R, Leyden JJ (1986) Topical tretinoin for photoaged skin. J Am Acad Dermatol 15:836-859

22. Krust A, Kastner P, Petkowich M, Zelent A, Chambon P (1989) A third human retinoic acid receptor, hRAR- $\gamma$. Proc Natl Acad Sci USA 86:5310-5314

23. Laborda J (1991) 36B4 cDNA used as an estradiol-independent mRNA control is the cDNA for human acidic ribosomal phosphoprotein PO. Nucleic Acids Res 19:3998

24. Madsen P, Rasmussen HH, Leffers H, Honoré B, Dejgaard K, Olsen E, Kiil J, Walbum E, Andersen AH, Basse B, Lauridsen JB, Ratz GP, Celis A, Vandekerckhove J, Celis JE (1991) Molecular cloning, occurrence, and expression of a novel partially secreted protein ,psoriasin“" that is highly up-regulated in psoriatic skin. J Invest Dermatol 97:701-712

25. Orfanos CE, Ehlert R, Gollnick H (1987) The retinoids. A review of their clinical pharmacology and therapeutic use. Drugs 34:459-503

26. Piletta P, Jaconi S, Siegenthaler G, Didierjean L, Saurat JH (1994) Topical glucocorticosteroids modulate the expression of CRABP I and II in human skin differently. Exp Dermatol $3: 23-28$

27. Sitzmann J, Algermissen B, Czarnetzki BM, LeMotte P (1993) Expression of psoriasin mRNA in several human skin diseases. J Invest Dermatol 100:220

28. Tavakkol A, Elder JT, Griffiths CEM, Cooper KD, Talwar H, Fischer Gj, Keane KM, Foltin SK, Voorhees JJ (1992) Expression of growth hormone receptor, insulin-like growth factor 1 (IGF-1) and IGF-1 receptor mRNA and proteins in human skin. J Invest Dermatol 99:343-349

29. Tavakkol A, Griffiths CEM, Keane KM, Palmer RD, Voorhees JJ (1992) Cellular localization of mRNA for cellular retinoic acid-binding protein II and nuclear retinoic acid receptor- $\gamma 1$ in retinoic acid-treated human skin. J Invest Dermatol 99:146150

30. Tavakkol A, Zouboulis ChC, Duell EA, Voorhees JJ (1994) A retinoic acid-inducible skin-specific gene (RIS-1): molecular cloning and analysis of gene expression in human skin in vivo and cultured skin cells in vitro. Mol Biol Rep 20:75-83

31. Törmä H, Löntz W, Liu W, Rollman O, Vahlquist A (1994) Expression of cytosolic retinoid-binding protein genes in human skin biopsies and cultured keratinocytes and fibroblasts. Br J Dermatol 131:243-249

32.Zouboulis ChC, Tavakkol A (1994) Storage phosphor imaging technique improves the accuracy of RNA quantitation using ${ }^{32}$ P-labeled cDNA probes. Biotechniques 16:290-294 